2014s-34

\title{
CSR related management practices and Firm Performance: An Empirical Analysis of the Quantity-Quality Trade-off on French Data
}

Patricia Crifo, Marc-Arthur Diaye, Sanja Pekovic

\section{Série Scientifique \\ Scientific Series}

\author{
Montréal \\ Juillet 2014
}

(C) 2014 Patricia Crifo, Marc-Arthur Diaye, Sanja Pekovic. Tous droits réservés. All rights reserved.

Reproduction partielle permise avec citation du document source, incluant la notice $($ ).

Short sections may be quoted without explicit permission, if full credit, including (C) notice, is given to the source.
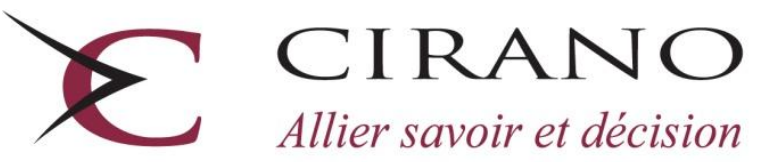

Allier savoir et décision

Centre interuniversitaire de recherche en analyse des organisations 


\section{CIRANO}

Le CIRANO est un organisme sans but lucratif constitué en vertu de la Loi des compagnies du Québec. Le financement de son infrastructure et de ses activités de recherche provient des cotisations de ses organisations-membres, d'une subvention d'infrastructure du Ministère de l'Enseignement supérieur, de la Recherche, de la Science et de la Technologie, de même que des subventions et mandats obtenus par ses équipes de recherche.

CIRANO is a private non-profit organization incorporated under the Québec Companies Act. Its infrastructure and research activities are funded through fees paid by member organizations, an infrastructure grant from the Ministère de l'Enseignement supérieur, de la Recherche, de la Science et de la Technologie, and grants and research mandates obtained by its research teams.

\section{Les partenaires du CIRANO}

\section{Partenaire majeur}

Ministère de l'Enseignement supérieur, de la Recherche, de la Science et de la Technologie

\section{Partenaires corporatifs}

Autorité des marchés financiers

Banque de développement du Canada

Banque du Canada

Banque Laurentienne du Canada

Banque Nationale du Canada

Bell Canada

BMO Groupe financier

Caisse de dépôt et placement du Québec

Fédération des caisses Desjardins du Québec

Financière Sun Life, Québec

Gaz Métro

Hydro-Québec

Industrie Canada

Intact

Investissements PSP

Ministère des Finances et de l'Économie

Power Corporation du Canada

Rio Tinto Alcan

Ville de Montréal

\section{Partenaires universitaires}

École Polytechnique de Montréal

École de technologie supérieure (ÉTS)

HEC Montréal

Institut national de la recherche scientifique (INRS)

McGill University

Université Concordia

Université de Montréal

Université de Sherbrooke

Université du Québec

Université du Québec à Montréal

Université Laval

Le CIRANO collabore avec de nombreux centres et chaires de recherche universitaires dont on peut consulter la liste sur son site web.

Les cahiers de la série scientifique (CS) visent à rendre accessibles des résultats de recherche effectuée au CIRANO afin de susciter échanges et commentaires. Ces cahiers sont écrits dans le style des publications scientifiques. Les idées et les opinions émises sont sous l'unique responsabilité des auteurs et ne représentent pas nécessairement les positions du CIRANO ou de ses partenaires.

This paper presents research carried out at CIRANO and aims at encouraging discussion and comment. The observations and viewpoints expressed are the sole responsibility of the authors. They do not necessarily represent positions of CIRANO or its partners.

ISSN 2292-0838 (en ligne)
Partenaire financier

Enseignement supérieur. Recherche, Science et Technologie Québec 


\title{
CSR related management practices and Firm Performance: An Empirical Analysis of the Quantity- Quality Trade-off on French Data
}

\author{
Patricia Crifo ${ }^{\dagger}$, Marc-Arthur Diaye ${ }^{+}$, Sanja Pekovic ${ }^{\S}$
}

\begin{abstract}
Résumé/abstract
This paper analyzes how different combinations of Corporate Social Responsibility (CSR) dimensions affect corporate economic performance. We use various dimensions of CSR to examine whether firms rely on different combinations of CSR, in terms of quality versus quantity of CSR practices. Our empirical analysis based on an original database including 10,293 French firms shows that different CSR dimensions in isolation impact positively firms' profits but their effect in term on intensity varies among CSR dimensions. Moreover, the findings on the qualitative CSR measure, based on interaction between its dimensions, show that the substitutability of these dimensions is highly significant for firm performance. However, in terms of the intensity, those interactions produce differential effects.
\end{abstract}

Mots-clés/Key words: corporate social responsibility, firm performance, substitutability, complementarity, trade-off, simultaneous equations models.

\footnotetext{
* Acknowledgements: Support of the Chair for Sustainable Finance and Responsible Investment (Toulouse-IDEI and Ecole Polytechnique) is gratefully acknowledged by Patricia Crifo. Marc-Arthur Diaye and Sanja Pekovic gratefully acknowledge the support from the AFNOR "Performance des Organisations" endowment in collaboration with the University Paris-Dauphine Foundation. Marc-Arthur Diaye acknowledges the support of the Rennes Metropole "Allocation d'Installation Scientifique" and the Commissariat General à la Stratégie et à la Prospective. The authors are also grateful to Marcus Wagner, Mareva Sabatier and the seminar participants at the University of Wuerzburg, the University of Annecy and the ESG Management School, for useful comments and suggestions.

${ }^{\dagger}$ University of Paris West, EcolePolytechnique (Palaiseau, France) and CIRANO (Montreal, Canada). patricia.crifo@polytechnique.edu

"University Evry Val d'Essonne (EPEE). marc-arthur.diaye@ univ-evry.fr.

${ }^{\S}$ University of Paris-Dauphine (DRM-DMSP-CNRS UMR 7088). sanja.pekovic@dauphine.fr.
} 


\section{INTRODUCTION}

In all OECD countries, firms are making a lot of effort to be, or at least to appear, socially responsible. In 2005, for instance, 52\% of the top 100 corporations in the 16 most industrialized countries published reports on their corporate and socially responsible activities. In fact, since the late 1990s, many industrialized countries have adopted laws requiring firms (listed and/or non listed) to publish reports detailing their exposure to environmental, social and governance risks and how they address these risks. ${ }^{1}$

Nevertheless, Corporate Social Responsibility (CSR) means socially and environmentally friendly actions not only required by law, but going beyond compliance, privately providing public goods or voluntarily internalizing externalities. According to the European Commission (2007), being socially responsible in fact means that, beyond legal requirements, firms accept to bear the cost of more ethical behavior by voluntarily committing, for instance, to improving employment conditions, banning child labor and not working with countries that do not respect human rights, protecting the environment and investing in equipment to reduce their carbon footprint, developing partnerships with NGOs, providing funds to charity, etc. CSR strategies would in fact allow firms to maximize value and to minimize risk in the long run, to respond to increased competitive pressure and market differentiation, and such strategies would more generally take into account the growing demands of their stakeholders (customers, consumers, employees, investors). But do firms actually benefit from CSR strategies? Can it be profitable to invest in responsible practices beyond legal obligations? In

\footnotetext{
${ }^{1}$ Laws "New economic regulation" (2001) and "Grenelle II" (2010) in France, "Sarbanes-Oxley" (2002) and Greenhouse gas reporting rule (2010) in the US, "Social responsibility for large businesses" (2008) in Denmark, "Sustainability reporting" (2013) in Norway, "Companies Act" (2006) and "Carbon reduction commitment" (2010) in the UK, "Sustainable economy" (2011) in Spain etc.
} 
other words, what are the links between CSR and corporate economic performance? In turn, what is the value of CSR strategies, in particular with respect to social, environmental or market behavior?

The impact of Corporate Social Responsibility on corporate economic performance has received considerable attention in the literature over the past three decades (see e.g. Margolis et al., 2009 for comprehensive reviews). However, even if several studies using meta-analyses (Margolis et al., 2009; Margolis and Walsh, 2003; Orlitzky et al., 2003) conclude that the relationship between CSR and firms is non-negative, there is no unanimity so far. Social responsibility rather seems to have an ambiguous and complex impact on firm performance though no true causality has been proved yet. While some research argues that investment in social responsibility raises a firm's costs, which makes it less competitive (Friedman, 1970; Brummer, 1991; McWilliams and Siegel, 1997), other research has suggested that by investing in social performance, a firm can achieve competitive advantage by attracting resources and quality employees more easily, differentiating its products and services, reducing its exposure to risk, etc. (Cochran and Wood, 1984; Turban and Greening, 1996; Waddock and Graves, 1997; McWilliams and Siegel, 2001; Godfrey, 2004).

According to Cavaco and Crifo (2013) one reason for this absence of consensus lies in the possibility of a quantity-quality trade-off between the various dimensions of corporate responsibility, where quantity refers to the effect of the CSR dimensions in isolation and taken together and quality corresponds to interactions between various CSR dimensions. A firm's CSR policy is multi-dimensional and includes environmental, social and business behavior factors. Consequently, using a single item as a proxy for generic CSR could cause fundamental uncertainty about the relationship between CSR and firm performance (e.g. Surroca, Tribò and Waddock, 2010). In this sense, Mackey, Mackey and Barney (2007), 
Brammer and Milligton (2008) and Barcos et al. (2013) suggest that some forms of socially responsible behavior are positively associated with firm performance while other are not. Barnett and Solomon (2006) show that CSR investments vary by the intensity of a firm's social screening and also in the types of social screens that a firm employs. Hence, there is a need to break down the CSR among the different dimensions in order to study its possible differential impact on a firm performance (Barcos et al., 2013). Moreover, how those various dimensions interact as inputs of firm performance is important. In a context of limited resources, firms may well face a quantity (specific practices or number of practices employed) or quality (interactions among practices employed) trade-off effect, suggesting a complex and ambiguous impact of various CSR combinations on business performance. Thus, we test whether such a quantity-quality trade-off emerges using data on French firms from the Organizational Change and Computerization survey (COI, 2006).

To measure CSR, existing studies often focus on CSR scores or ratings provided by extrafinancial rating agencies like KLD in the US or Vigeo in Europe. This study uses secondary data on CSR performance. "Secondary data is useful not only to find the information to solve our research problem, but also better understand and explain our research problem" (Ghauri and Gronhaug, 2005). Actually, the interest of the COI survey is that it provides quantitative metrics of CSR related management practices rather than extra-financial evaluation. As emphasized by Chatterji, Levine and Toffel (2009), extra-financial ratings are rarely evaluated and have been criticized for their own lack of transparency. Therefore, our measures of CSR related management practices offer a different but complementary approach to such social and environmental ratings as they rely on actual practices implemented by the firms, rather than evaluations (scores or ratings) based on past and/or expected future CSR behaviors. The limitation of our variables is that we do not cover CSR management practices related to human rights, community involvement or corporate governance. In this sense, our research is 
more focused on stakeholder oriented CSR practices, notably towards employees, or customers and suppliers (Barcos et al., 2013. Yet, our database relies on a representative sample of more than 10,000 French firms, whereas extra-financial agencies cover only several hundred (multinational) firms.

Our results indicate that CSR management related practices in isolation impact positively on corporate performance measured by a firm's profit, while an aggregate CSR indicator (measuring a purely quantitative strategy) is positively associated with firm profit only when having at least two dimensions. Moreover, the qualitative CSR measure based on interaction among its dimensions shows that the substitutability of these dimensions is highly significant for firm performance. It is worth noting that different isolation forms and interactions of CSR dimensions produce different effects on firm performance in terms of intensity.

We believe that these results contribute to the CSR literature in several ways. First, rather than simply investigating the impact of one CSR dimension on firm performance, we analyze how different combinations of CSR dimensions affect firm performance measured by profit. Second, we use data on a representative sample of French firms, which permits us to construct two types of variables from the aforementioned questions. Additionally, employing this data allows us to control for a very detailed set of firm characteristics and features in order to properly isolate the effect on firm performance of the quantity-quality trade-off between CSR dimensions, to address the reverse-causality issues and to properly correct for the endogeneity of CSR variables. Finally, using a French database is appealing since empirical studies on CSR and firm business performance refer mainly to experience in US firms.

This paper is organized as follows. Section 2 reviews the core of our analysis while section 3 builds testable hypotheses. Section 4 presents the data and method. Section 5 presents our empirical results and discusses the findings, and section 6 concludes the paper. 


\section{HYPOTHESES}

It is becoming conventional wisdom today to define corporate social responsibility through the lenses of three main dimensions: environmental, social and governance (the so-called ESG factors). In turn, and drawing on previous research (e.g. Waddock and Graves, 1997; Cavaco and Crifo, 2013; Barcos et al., 2013), we define CSR relying on three main categories: environmental performance, human resource related practices, and relationships with customers \& suppliers.

\section{Isolated and Aggregated Effect of CSR Dimensions on Firm Performance}

Previous studies underline the differential effects of CSR dimensions on firm performance (e.g. Brammer and Pavelin, 2006; Barcos et al., 2013). Therefore, it is likely that the impact of CSR on firm performance is contingent upon which dimension of social responsiveness is taken into consideration. Furthermore, the issue of whether each of our three dimensions of CSR (environmental performance, human resources performance, and relationships with customers \& suppliers) is related to firm performance is far from resolved. For instance, several studies find a positive relationship between environmental practices or performance and economic performance (see e.g. Delmas and Pekovic, 2013; Lo et al., 2012), but other results appear to be negative or non-significant (Barla, 2007; Filbeck and Gorman, 2004). The same types of results may be found for human resource measures. Improving human resource practices may appear to affect performance positively (Huselid, 1994) or negatively (Gimenez, Sierra and Rodon, 2012). For the customer \& supplier dimension, many scholars note its importance for firms and an increasing number of recent studies are now examining whether investment in customer and supplier policies makes business sense. Results appear mixed as well (Zhu and Nakata, 2007; Yeng, 2008; Lin et al., 2005; Reitzig and Wagner, 
2010). For instance, Yeung (2008) concludes that strategic supply management leads to improved on-time shipments and reduced operational costs, and leads to customer satisfaction and improved business performance. On the other side, investment in better relations with suppliers may create for a firm the opportunity costs of non-learning, which could negatively affect its performance (Reitzig and Wagner, 2010). Inherently a multi-dimension construct, there is no reason to believe that one dimension (say the customer \& supplier dimension) affects firm performance in the same direction as another one (say environmental). In fact, different costs and revenues characterize management practices, affecting firm performance differently.

Thus, the first step in order to understand better the relationship between CSR and firm performance is to open the black box by examining how CSR dimensions in isolation and in aggregation influence firm performance. Although the literature argues that the relationship between different dimensions of CSR and firm performance is not straightforward, extensive research conducted over the past 30 years is in line with studies that tend to show a positive relationship, or at least not a negative one, between CSR dimensions and financial performance (Margolis et al., 2009; Margolis and Walsh, 2003; Orlitzky et al., 2003). Therefore we formulate the following hypothesis:

Hypothesis 1A: Isolated CSR dimensions exert a positive impact on firm performance.

Even if creating an aggregated measure of CSR hides the individual effects of each CSR dimension, using an aggregated construct of CSR may facilitate inter-firm comparison on the level of CSR established inside firms. However, previous research using aggregated CSR constructs presents inconsistency in findings concerning the relationship between CSR and firm performance (e.g. Waddock and Graves, 1997; Surroca et al., 2010). Moreover, given the 
importance of each dimension of CSR for firm performance, we expect that overall the firm's tendency to demonstrate its social responsibility is positively associated with the firm's performance, and propose the following hypothesis:

Hypothesis 1B: Aggregate measure of CSR exerts a positive impact on firm performance.

\section{The Complementarity or Substitutability Effect of CSR Dimensions}

The contradictory results or the absence of consensus concerning the relationship between CSR and firm performance may be explained by the role of interactions among the various components of CSR. Taking into account the interaction among various CSR dimensions reveals that complex mechanisms are at work in terms of responsible management practices, with combinations exhibiting both complementarity and substitutability (see Cavaco and Crifo, 2013). It is important to point out that the definitions of complementarity and substitutability that we use are borrowed from Athey and Stern (1998), and they are actually close to the notions of supermodularity and submodularity in game theory. The definitions of complementarity and substitutability by Athey and Stern (1998) might seem counterintuitive with respect to conventional wisdom (at least concerning complementarity between goods) which associates complementarity with positive correlation and substitutability with negative correlation. Following Athey and Stern (1998), two CSR practices can both be positively correlated and substitutable. More precisely, having more than one CSR practice creates a complementary effect if the magnitude of the performance effect of these management practices altogether is strictly larger than the sum of the marginal effects from adopting only one practice (Ichniowski et al., 1997). In this sense, complementarity indicates that firms are likely to combine a set of practices since the benefits of such a complete pattern of practices are superior to the sum of the individual benefits (Whittington et al., 1999). A reason could be 
the existence of a synergistic effect of bundling practices together. What type of CSR practices can we expect to be complementary? The Stakeholder theory of the firm argues that managing relationships between primary stakeholders (suppliers of capital, labor and other resources, customers and suppliers) can result in much more than just their continued participation in the firm, and yield long term competitive advantage (Hillman and Keim, 2001). Hence, we may expect complementarities between CSR related management practices towards primary stakeholders like employees, customers and suppliers.

A substitutability effect between CSR practices means exactly the opposite here. One can explain substitutability by the fact that although CSR dimensions have the same final objective, individually they act differently. For instance, one firm can have great relations with its customers but also has a reputation for polluting the environment. The good relations with customers could not compensate for the environmental degradation. In this sense, Berens et al. (2007), examining the effect on product preferences, find that a poor corporate ability could not be compensated by good CSR. Moreover, based on decision-making theory, it is argued that in forming a general evaluation, negative attributes tend to outweigh positive attributes (e.g. Baumeister et al., 2001). Thus, we may argue that existing CSR dimensions inside a firm cannot compensate for missing CSR dimensions. Additionally, according to decision-making theory (see the so-called Choquet integral, Grabisch 1997), when two dimensions share some similar "substantial" attributes, then the interaction between these dimensions leads to substitutability. For instance, green and customer \& supplier dimensions share some similar "substantial" attributes in the sense that it is difficult to implement a green dimension within a firm without implementing some attributes of the customer \& supplier dimension (Lehtonen, 2004; OCDE, 2006²). Indeed, environmental practices have become critical to a firm's relationships with different stakeholder groups such as customers and

\footnotetext{
${ }^{2}$ http://www.oecd.org/environment/36958774.pdf
} 
suppliers (Barnett and Salomon, 2006; Grolleau, Mzoughi and Pekovic, 2007). As a consequence, when implementing both dimensions, the effect on the firm's performance will be equal to the sum of the effect of the green dimension and the effect of the attributes of the customer \& supplier dimension that are not shared by the green dimension. On the contrary, if two dimensions do not share similar "substantial" attributes, then the interaction between these dimensions leads to complementarity or additivity. Finally we can use also the stakeholder theory of the firm in order to predict the complementarity or substitutability of our three CSR dimensions. According to this theory, using corporate resources to pursue issues that are not directly related to the relationship with primary stakeholders may not lead to sustained competitive advantage (Hillman and Keim, 2001). Here, this would mean that there should exist some trade-offs (substitutability) between primary and non-primary stakeholders (Cavaco and Crifo, 2013), that is between CSR practices towards employees, and customers and suppliers on the one hand; and towards the environment on the other hand. In fact, though the environment may be quoted as a stakeholder, it is often difficult to identify a direct spokesperson and therefore to embed it into the firm's primary stakeholder category.

To conclude we expect a complementarity effect between human resources and customer \& supplier dimensions ${ }^{3}$; and substitutability effects between green and human resources dimensions; green and customer \& supplier dimensions.

We formulate the following hypothesis:

Hypothesis 2: The interaction among different CSR dimensions generates:

\footnotetext{
${ }^{3}$ Even though one could argue that a firm's customer and supplier orientation strategy is based on some social attributes, we consider that they are not strong enough to produce the substitutability effect between social and customer \& supplier dimensions. For instance, as argued by Ferrell (2004), in a highly competitive market, a firm could both have anti-social behavior and be strongly customer oriented.
} 
- substitutability effects between green and HR; green and customer \& supplier; green, HR, customer \& supplier;

- complementarity effects between HR and customer \& supplier.

\section{DATA AND METHOD}

\section{Data}

The data is extracted from the French Organizational Changes and Computerization (COI) 2006 survey. ${ }^{4}$ The COI survey is a matched employer-employee dataset on organizational change and computerization. Researchers and statisticians from the National Institute for Statistics and Economic Studies (INSEE), the Ministry of Labor, and the Center for Labor Studies (CEE) created this survey. The survey contains about 13,790 private sector firms with at least 10 employees each. It is a representative population of French firms from all business sectors except agriculture, forestry and fishing. Each firm filled in a self-administered questionnaire concerning the utilization of information technologies and work organizational practices in 2006, and changes that had occurred in those areas since 2003. Firms were also interviewed on the economic goals driving the decision to implement organizational changes and the economic context in which those decisions were made.

In order to obtain information on export volumes and profitability, the COI survey was merged with another database called the Annual Business Survey (EAE, 2003 and 2006). ${ }^{5}$ We use two editions of the EAE survey from 2003 (to obtain information on exports volumes and

\footnotetext{
${ }^{4}$ More details about the design and scope of this survey are available on www.enquetecoi.net: Survey COI-TIC 2006-INSEE-CEE/Treatments CEE.

${ }^{5}$ More details about the design and scope of this survey are available on http://www.insee.fr/en/methodes/default.asp?page=definitions/enquete-annuelle-entreprises.htm
} 
sales) and from 2006 (to obtain information on profit). As a result, our sample includes 10,293 firms.

\section{Dependent and Main Independent Variables}

We use as dependent variable firm's profit per employee. Existing studies often rely on accounting measures of financial performance (e.g. return on asset, return on equity, return on capital employed, return on sales) or market-based measures of financial performance (e.g. Tobin's q), mainly because of data availability. Nevertheless, a few papers rely on firm profitability indicators. For instance, Brammer and Pavelin (2006) use the ratio of pre-tax profits to total assets and Fernandez-Kranz and Santalo (2010) use average profits (in dollars) to control for firm profitability in their empirical estimations.

Our analysis provides a different but complementary approach to papers focusing on accounting or market measures. In fact, accounting measures are backward looking and capture past financial performance, but are subject to bias from managerial manipulation and differences in accounting procedures. Market measures are forward looking and are less dependent on accounting procedures but only represent the investor's evaluation of the ability of a firm to generate future economic earnings. Basically, profitability indicators (like profit margins or ratio) are usually considered as reflecting productivity whereas economic profitability would be captured by accounting measures, and market value would be captured by market-based measures.

Concerning the main independent variables, the COI survey allows reliance on direct indicators of CSR related management practices grouped under three dimensions. More precisely, like Barcos et al. (2013) we use three CSR dimensions: green practices, human resources practices, and business behavior towards customers and suppliers. This approach is consistent with existing studies, which measure CSR with extra-financial ratings either 
through scores (e.g. continuous variable over the 0-100 interval) or through relative rankings, represented by a dummy variable that takes the value of 1 (respectively 0 ) if the firm is ranked above (respectively below) the sectoral average on the corresponding CSR dimension (see Cavaco and Crifo, 2013).

Our approach offers a perspective on CSR related management practices different to studies based on extra-financial scores or ratings provided by agencies such as KLD in the US or Vigeo in Europe. As emphasized in Chatterji, Levine and Toffel (2009), extra-financial rating examines firms' environmental and social management activities and past performance, as well as future outlook. Such ratings aim to provide socially responsible investors with accurate information that makes transparent the extent to which firms' behaviors are socially responsible. They usually rely on a variety of areas of corporate social responsibility. For instance, the European extra-financial agency Vigeo produces scores and ratings relying on six CSR dimensions: environment, human rights, human resources, governance, business behaviors towards customers and suppliers, and societal commitment towards local communities. Similarly, the American extra-financial agency KLD produces "strengths" and “concerns" relying on seven CSR dimensions: community, corporate governance, diversity, employee relations, environment, human rights, and product and business behaviors. For each dimension, there is a subset of criteria describing how the firm manages a particular aspect of the CSR dimension. However, several studies have criticized the measures used in the KLD database (e.g. Chen and Delmas, 2011).

Here, our variables may seem less complete than those based on extra-financial scores. Our approach does not include the human rights, governance and societal commitment dimensions simply because we do not have such information in our database. We are mainly oriented towards stakeholder associated CSR practices (Barcos et al., 2013). Furthermore, the advantages of the COI survey are to allow 1) the measuring of CSR directly through a CSR 
performance measure, 2) a CSR performance measure for 10,293 firms which are representative of French firms. As a consequence, we expect more precise estimates.

Note in addition that our four CSR related dimensions give a precise content to the conventional definition of CSR by the European Commission as "a concept whereby companies integrate social and environmental concerns in their business operations and in their interaction with their stakeholders by voluntarily taking on commitments which go beyond common regulatory and conventional requirements" (European Commission 2001). We have matched the COI survey with the Vigeo dataset and it appears that 21 firms are in both datasets. Within these 21 firms, we checked for the link between our CSR construction and the Vigeo ratings. We found that our CSR construction includes a part of the information conveyed by the Vigeo ratings.

Our CSR related dimensions are defined as follows.

Green. We use in the survey the variable denoted Green, which is a binary variable, coded 1 if the firm was registered according to one of the following standards i.e., ISO 14001 standard, organic labeling, fair trade, etc., in 2003.

Human Resources $(H R)$. We construct a human resources indicator which presents the sum of the following six components: (1) it is very important or important for the firm to improve employee relations/ skills and keep its employees; (2) the firm had central databases for human resources, training in 2003; (3) the firm had had internal and (4) external departments focused on human resources, training since 2003; (5) the firm used the internet for employees' learning or training in 2003. Moreover, in order to test our hypothesis concerning the complementarity and trade-off effects between CSR dimensions, we must harmonize the values of each CSR dimension. We solve this problem by converting the HR dimension into a binary variable that takes the value of 1 if the HR component is equal or superior to 2.11 (the mean of the sum of the previously mentioned components). 
Customer \& Supplier. We construct a customer \& supplier indicator as the sum of eleven following items: (1) the firm used labeling tools for goods and services in 2003; (2) the firm was engaged in the delivery or supply of goods or services to a fixed deadline in 2003 ; (3) the firm had a contact or call center for customers in 2003; (4) the firm had adopted integrated ITCRM in 2003; (5) the main customer demanded that the firm comply with a quality standard or quality control procedure in 2003; (6) the firm used tools to study customer expectations, behavior or satisfaction in 2003; (7) the firm had had internal departments focused on improving safety and environmental issues since 2003; (8) the firm had signed contracts or was engaged with some suppliers in long term relationships in 2003; (9) on the firm's demand, the main supplier complied with a quality standard or quality control procedure in 2003; (10) the main supplier had an IT system (for orders, invoices, etc.) linked to that of the firm's in 2003; (11) the firm was registered according to the ISO 9000 standard (quality management).

For the Customer \& Supplier dimension, we calculate the mean of the sum of these eleven components and create a binary variable that takes the value of 1 if the customer and supplier component is equal or superior to 4.03 (the mean value of the sum).

From these three binary CSR dimensions, we constructed two types of variables:

$C S R$. In order to test the effect of aggregate measure of Corporate Social Responsibility on firm performance we create the variable $C S R$, which sums up the three (binary) dimensions: (1) green; (2) HR; (3) customer \& supplier. From this CSR variable which varies from 0 to 3, we create three binary variables:

- CSR_1_0 = 1 if the firm had invested in only one CSR dimension; and = 0 if the firm had not invested in any CSR dimensions; 
- CSR_2_0 = 1 if the firm had invested in two CSR dimensions; and $=0$ if the firm had not invested in any CSR dimensions;

- CSR_3_0 = 1 if the firm had invested in three CSR dimensions; and $=0$ if the firm had not invested in any CSR dimensions;

Interaction. To investigate the effect of complementarity and synergies between CSR dimensions, we create seven variables, namely:

- Interaction1_O = 1 if the firm had invested only in green practices; and $=0$ if the firm had not invested in any CSR dimensions;

- Interaction2_O $=1$ if the firm had invested only in HR practices; and $=0$ if the firm had not invested in any CSR dimensions;

- Interaction3_O = 1 if the firm had invested only in customer \& supplier dimensions; and $=0$ if the firm had not invested in any CSR dimensions;

- Interaction4_O $=1$ if the firm had invested in both green and HR dimensions; and $=0$ if the firm had not invested in any CSR dimensions;

- Interaction5_0 = 1 if the firm had invested in both green and customer \& supplier dimensions; and $=0$ if the firm had not invested in any CSR dimensions;

- Interaction6_O = 1 if the firm had invested in both HR and customer \& supplier dimensions; and $=0$ if the firm had not invested in any CSR dimensions;

- Interaction7_ $0=1$ if the firm had invested in all practices; and $=0$ if the firm did had not invested in any CSR dimensions.

\section{Controls}

In order to control for firm-level heterogeneity, our analysis includes variables representing firm characteristics and features based on previous studies, specifically those relating to 
Corporate Social Responsibility and firm performance (e.g. Capon et al., 1990; Waddock and Graves, 1997; Russo and Fouts, 1997; McWilliams and Siegel, 2000; Brammer and Milligton, 2008).

Size. In general, a positive relationship between Corporate Social Responsibility and size is found (e.g. Waddock and Graves, 1997; McWilliams and Siegel, 2000; Brammer and Milligton, 2008). Substantial research has also demonstrated that firm size significantly influences firm performance (e.g. Waddock and Graves, 1997), although the direction of its effect is not consistent (Russo and Fouts, 1997). So we introduce firm size, which is measured by a continuous variable representing the number of employees within the firm.

Holding. Being part of a holding company could play a considerable role in a firm's decision to invest in Corporate Social Responsibility since those firms might have more financial resources available to them for investment in new practices (Pekovic, 2010). Concerning the relation between holding and firm performance, it is argued that being part of a holding company could improve firm performance through economies of scope (Delmas and Pekovic, 2013). Hence, we include a dummy variable that takes a value of 1 when the firm belonged to a holding company in 2003.

Market Uncertainty. A firm that is socially responsible may be able to increase interpersonal trust between and among internal and external stakeholders, build social capital, lower transaction costs, and, therefore ultimately reduce uncertainty (Orlitzky and Benjamin, 2001). Miller and Bromiley (1990) argue that uncertainty negatively influences firm performance. Therefore, we include a binary variable representing whether the firm had been affected strongly or very strongly by market uncertainty since 2003 .

Market Conditions. Market expansion is expected to have positive influence on a firm's probability of investing in Corporate Social Responsibility practices (Russo and Fouts, 1997). Drawing on Capon, Farley and Hoenig (1990), we may suppose that market growth positively 
influences firm performance. In order to control for market conditions effects we use three binary variables indicating different market conditions since 2003: down market, steady market and growing market.

Export. Previous empirical studies have confirmed that export activities positively influence a firm's probability of investing in Corporate Social Responsibility practices (Grolleau et al., 2007; Delmas and Montiel, 2009; Pekovic, 2010). Export activities lead to firm performance improvements that have been identified as "learning by exporting" (Bernard et al., 2003). We use a continuous variable representing the firm's volume of exports divided by the firm's sales in 2003.

$R \& D$. McWilliams and Siegel (2000) argue that R\&D and CSR are positively correlated, since many aspects of CSR create either product innovation or process innovation, or both. A large amount of literature links investment in $R \& D$ to improvements in long-term economic performance (Griliches, 1979; Capon et al., 1990). In this study, R\&D is based on two variables that indicate if a firm collaborated on its R\&D activities in 2003 with private firms or laboratories, or with universities, the national center for research (CNRS), other public research organizations.

Advertising Intensity. A firm's CSR orientation might not be evident to the buyer directly, so advertising plays an important role in raising the awareness of those individuals who are interested in buying goods with CSR attributes (McWilliams and Siegel, 2000, 2001; Brammer and Pavelin, 2006; Brammer and Milligton, 2008). Capon et al. (1990), Russo and Fouts (1997) and McWilliams and Siegel (2000) consider advertising intensity as an important determinant of firm performance. To control for this effect, we create a variable denoted Advertising Intensity, which is based on two variables that indicate whether the firm has in 2003 a tracking or reporting system running at least quarterly to follow financial profitability or to plan activities. 
Business sector. The characteristics of a firm's business sector have been considered a key influence on its corporate social orientation (e.g. McWilliams and Siegel, 2000). The inclusion of the firm's sector is essential since it has been shown to explain variations in firm performance across industries, such as economies of scale and competitive intensity (McWilliams and Siegel, 2000). In order to control for sector differences, we include nine sector dummy variables based on the N36 sector classification created by the French National Institute for Statistics and Economic Studies: agri-foods; consumption goods; equipment goods; intermediate goods and energy; construction; sales; transport; financial and real-estate activities; and services to firms.

The variables used in the estimation, their definitions and sample statistics are presented in Table 1.

Table 1: Definition of variables and sample statistics

\begin{tabular}{|c|c|c|c|c|c|}
\hline Variable & Description & Mean & SD & Min & Max \\
\hline \multicolumn{6}{|c|}{ CSR related practices } \\
\hline Green & $\begin{array}{l}\text { Registered for ISO } \\
14001 \text {, organic labeling } \\
\text { or fair trade in } 2003\end{array}$ & 0.11 & 0.32 & 0 & 1 \\
\hline $\begin{array}{l}\text { Human } \\
\text { resources }\end{array}$ & $\begin{array}{l}\text { The firm invested in HR } \\
\text { practices in } 2003\end{array}$ & 0.36 & 0.48 & 0 & 1 \\
\hline $\begin{array}{l}\text { Customer \& } \\
\text { Supplier }\end{array}$ & $\begin{array}{l}\text { The firm invested in } \\
\text { customer and supplier } \\
\text { practices in } 2003\end{array}$ & 0.42 & 0.49 & 0 & 1 \\
\hline \multirow{7}{*}{ CSR } & \multicolumn{5}{|l|}{ The firm invested in 2003 in: } \\
\hline & all three practices; & 0.07 & 0.24 & 0 & 1 \\
\hline & two practices; & 0.21 & 0.41 & 0 & 1 \\
\hline & one practice; & 0.28 & 0.45 & 0 & 1 \\
\hline & $\begin{array}{l}\text { neither of the three } \\
\text { practices }\end{array}$ & 0.44 & 0.49 & 0 & 1 \\
\hline & \multicolumn{5}{|l|}{ The firm invested in 2003 in: } \\
\hline & $\begin{array}{l}\text { neither of the three CSR } \\
\text { practices; }\end{array}$ & 0.44 & 0.49 & 0 & 1 \\
\hline
\end{tabular}




\begin{tabular}{|c|c|c|c|c|c|}
\hline \multirow{7}{*}{ Intersection } & green practices only; & 0.01 & 0.12 & 0 & 1 \\
\hline & HR practices only; & 0.11 & 0.32 & 0 & 1 \\
\hline & $\begin{array}{l}\text { customer \& } \\
\text { practices only; }\end{array}$ & 0.15 & 0.36 & 0 & 1 \\
\hline & $\begin{array}{l}\text { both green and } \mathrm{HR} \\
\text { practices; }\end{array}$ & 0.01 & 0.08 & 0 & 1 \\
\hline & $\begin{array}{l}\text { both green and customer } \\
\& \text { supplier practices; }\end{array}$ & 0.03 & 0.17 & 0 & 1 \\
\hline & $\begin{array}{l}\text { both HR and customer \& } \\
\text { supplier practices; }\end{array}$ & 0.18 & 0.38 & 0 & 1 \\
\hline & all three dimensions & 0.07 & 0.24 & 0 & 1 \\
\hline Profit & $\begin{array}{l}\text { Logarithm of profit per } \\
\text { employee in } 2006\end{array}$ & 1.08 & 1.57 & -8.14 & 8.67 \\
\hline \multicolumn{6}{|c|}{ Instrumental variables } \\
\hline $\begin{array}{l}\text { Public } \\
\text { regulation }\end{array}$ & $\begin{array}{l}\text { The firm's business has } \\
\text { been affected since } 2003 \\
\text { by a change in } \\
\text { regulations, standards } \\
\text { (health, environment, } \\
\text { worker rights, etc.) }\end{array}$ & 0.52 & 0.5 & 0 & 1 \\
\hline $\begin{array}{l}\text { Workgroup } \\
\text { Tools }\end{array}$ & $\begin{array}{l}\text { The firm's uses in } 2003 \\
\text { some workgroup tools } \\
\text { (e.g. groupware, } \\
\text { videoconference, etc.) }\end{array}$ & 0.18 & 0.4 & 0 & 1 \\
\hline \multicolumn{6}{|c|}{ Control variables } \\
\hline Size & Number of employees & 360.55 & $\begin{array}{l}2819.5 \\
3\end{array}$ & 10 & $\begin{array}{l}11195 \\
6\end{array}$ \\
\hline Holding & $\begin{array}{l}\text { Belong to a holding group } \\
\text { in } 2003\end{array}$ & 0.51 & 0.5 & 0 & 1 \\
\hline $\begin{array}{l}\text { Market } \\
\text { Uncertainty }\end{array}$ & $\begin{array}{l}\text { The firm has been } \\
\text { affected strongly or very } \\
\text { strongly by market } \\
\text { uncertainty since } 2003\end{array}$ & 0.6 & 0.5 & 0 & 1 \\
\hline \multirow[t]{4}{*}{$\begin{array}{l}\text { Market } \\
\text { Condition }\end{array}$} & \multicolumn{5}{|c|}{$\begin{array}{l}\text { How the market of the main activity of the firm has evolved since } \\
\text { 2003: }\end{array}$} \\
\hline & Down & 0.24 & 0.43 & 0 & 1 \\
\hline & Steady & 0.53 & 0.50 & 0 & 1 \\
\hline & Growing & 0.23 & 0.42 & 0 & 1 \\
\hline Export & $\begin{array}{l}\text { Share of firm exportation } \\
\text { by sales in } 2003\end{array}$ & 0.08 & 0.19 & 0 & 1 \\
\hline
\end{tabular}




\begin{tabular}{|c|c|c|c|c|c|}
\hline R\&D & $\begin{array}{l}\text { Related to its R\&D } \\
\text { activities in 2003, the } \\
\text { firm collaborated with (1) } \\
\text { private firms or } \\
\text { laboratories, (2) } \\
\text { universities, national } \\
\text { center for research (Cnrs), } \\
\text { other research public } \\
\text { organizations. }\end{array}$ & 0.2 & 0.4 & 0 & 1 \\
\hline Advertising & $\begin{array}{l}\text { The firm has in } 2003 \text { a } \\
\text { tracking or reporting } \\
\text { system running at least } \\
\text { quarterly to follow } \\
\text { financial profitability or } \\
\text { to plan activities. }\end{array}$ & 0.78 & 0.41 & 0 & 1 \\
\hline $\begin{array}{l}\text { Business } \\
\text { sectors (a) }\end{array}$ & $\begin{array}{l}\text { Agrifood, consumption } \\
\text { goods, cars and } \\
\text { equipment, intermediate } \\
\text { goods and energy, } \\
\text { construction, Sales, } \\
\text { transport, financial and } \\
\text { real-estate activities, } \\
\text { business services and } \\
\text { individual services. }\end{array}$ & & & & \\
\hline
\end{tabular}

a: Because of the table's length we do not report sample statistics for these variables.

No problem of high correlation between the variables was detected.

Because of the table's length we do not report Pearson correlation coefficients for these variables; the results are available from the author upon request.

\section{Estimation Strategy}

We can compare the results of our regressions because they have all the same reference, which is the case where no CSR dimension is implemented.

We run two kinds of estimates.

a. The first type of estimates

In the first type of estimates that we call Quantity estimates, we run three regressions with respectively CSR_1_0,CSR_2_0and CSR_3_0 as independent variables.

b. The second type of estimates 
In the second type of estimates that we call Quality estimates, we run seven regressions with respectively Intercation_1_0 to Interaction_7_0 as independent variables.

\section{Tackling the endogeneity issue}

It should be noted that the same factors (e.g. size, business sector, firm's strategy, etc.) may have an impact on firm performance and the firm's likelihood of investing in Corporate Social Responsibility, environmental standards, HR practices, and customer \& supplier practices. Thus, in order to correct for possible endogeneity, we rely on the Simultaneous Equations Model (SEM), which considers environmental standards, HR practices, and customer \& supplier practices, aggregation and interactions of CSR dimensions as endogenous variables. ${ }^{6}$ This model relies on a simultaneous estimation approach in which the factors that determine CSR dimensions, aggregation and its interactions (a) are estimated simultaneously with those defining the firm's profit (b). The two equations are jointly estimated using maximum likelihood.

In the following SEM, $Y_{1}^{*}$ and $Y_{2}^{*}$ are latent variables that respectively, influence the probability of firms investing in different combinations of CSR dimensions and improving their profitability:

$$
\left\{\begin{array}{l}
(a) Y_{1}^{*}=\alpha_{1}+\beta_{1} X_{1}+\delta_{1} Z_{1}+\mu_{1} \\
(b) Y_{2}^{*}=\alpha_{2}+\beta_{2} X_{2}+\gamma_{2} Y_{1}+\mu_{2}
\end{array}\right.
$$

where $X_{1}$ and $X_{2}$ are here the same and include some exogenous variables such as characteristics and features of the firm such as size, being a part of a holding group, market

\footnotetext{
${ }^{6}$ Let us note that in our case, the explanatory variables that are supposed to be endogenous are dummy variables like the environmental standards, social practices and customer \& supplier practices. We use the Roodman (2009) cmp command in Stata in order to estimate our model. The advantage of this command is that it allows for different formats (e.g. binary, censored and continuous) of the dependent variables in the system of equations.
} 
uncertainty, market conditions, export activities, R\&D strategy, advertising and business sector.

In our case, $\mathrm{Y}_{2}{ }^{*}$ is fully observed, however $\mathrm{Y}_{1}{ }^{*}$ is observed (and then written $\mathrm{Y}_{1}$ ) if it is higher than a threshold. The variable $Z_{1}$ represents the vector of instrumental variables that guarantee the identification of the model and facilitate the estimation of correlation coefficients (Maddala 1983). A SEM circumvents the problem of interdependence by using instrument variables to obtain predicted values of endogenous variables (in our case, CSR dimensions, aggregation form of CSR and its intersections). Since we take $X_{1}$ and $X_{2}$ as identical, then in order to identify the model, we need some (at least one) additional variables (included in $Z_{1}$ ) that explain the probability of the firm investing in CSR or its dimensions but are not correlated with the error term of firm performance equation. More precisely, we include two variables in $Z_{1}$ :

(1) Firm's business had been affected since 2003 by a change in regulations, standards (health, environment, worker rights, etc. $)^{7}$.

(2) Firm used in 2003 some workgroup tools (e.g. groupware, videoconference, etc.) ${ }^{8}$.

As can be seen in the appendix, the choice of these variables is wise from a statistical standpoint.

\footnotetext{
${ }^{7}$ This variable is related to law, hence to public regulation. According to the concept of "articulated regulation", there is a link between private collective self-regulation (which CSR is a part of) and public regulation (Utting 2005).

${ }^{8}$ Workgroup tools are considered as an important instrument of a firm's social responsiveness toward employees (Surocca et al., 2010) and then may affect Corporate Social Responsibility. Using group work tools could help employees to enhance their knowledge and motivation to understand the problems, identify solutions and implement improved practices related to social responsibility (Hart, 1995).
} 
Finally to address reverse-causality issues, given that strong profitability will allow a firm to invest time and effort in CSR and its dimensions, we model lagged effects by estimating the impact of investment in CSR in 2003 on profit in 2006.

\section{How to check the hypotheses $1 A, 1 B$ and 2?}

- In order to test the Hypothesis 1A (i.e. isolated CSR dimensions exert a positive impact on firm performance), we take as the reference the case where no CSR dimension is implemented and we look at the effect of (1) green practices only, (2) HR practices only, and (3) customer \& supplier only, on firm's profit.

- In order to test the Hypothesis 1B (i.e. aggregate measure of CSR exerts a positive impact on firm performance), we take as the reference the case where no CSR dimension is implemented and we look at the effect on a firm's profit of (1) having one CSR dimension, (2) having two CSR dimensions, (3) having all three CSR dimensions.

- In order to test the Hypothesis 2 concerning complementarity and substitutability in the sense of Athey and Stern $1998^{9}$, we look at the coefficients associated with the interaction variables when examining their impact on profit. For instance, Interaction5_0 presents the interaction between green and customer \& supplier practices. Let $\alpha 5$ be the associated coefficient. If $\alpha 5>\alpha 1+\alpha 3$, where $\alpha 1$ and $\alpha 3$ are respectively the coefficient associated with Interaction1_0 (having only green practices) and Interaction3_0 (having only customer \& supplier practices), then we conclude that there is a complementarity between the green and the customer \& supplier dimensions of CSR. Otherwise there is a substitutability.

We choose to work on sub-samples having the same reference instead of working on the whole sample, because in the first case, $\mathrm{Y}_{1}$, the dependent variable in the equation (a) of

\footnotetext{
${ }^{9}$ We use the definition by Athey and Stern (1998), when the choice is binary and the interaction effects are fixed across firms.
} 
model (1) is binomial (making it easier to estimate model (1) by maximum likelihood) while in the second case it is multinomial.

\section{EMPIRICAL RESULTS AND DISCUSSION}

The main results of the SEM estimations are summarized in Tables 2 and 3. Note that the full results (Appendix 1) also provide information about the determinants of CSR dimensions and firm profitability. Even though we will not discuss these results, we may conclude that they generally confirm the findings of previous studies (e.g. Capon et al., 1990; Waddock and Graves, 1997; Russo and Fouts, 1997; McWilliams and Siegel, 2000; Brammer and Milligton, 2008).

Table 2: Qualitative estimations

\begin{tabular}{|c|c|c|}
\hline Type of Interaction & Sign & Coefficient \\
\hline \multicolumn{3}{|c|}{ One dimension } \\
\hline Green practices only & + & $0.53^{* * *}$ \\
\hline HR practices only & + & $0.52 * * *$ \\
\hline Customer \& Supplier practices only & + & $0.30^{*}$ \\
\hline \multicolumn{3}{|c|}{$\begin{array}{ll} & \text { Two dimensions } \\
\end{array}$} \\
\hline Green and HR practices & + & $0.59 *$ \\
\hline Green and Customer \& Supplier practices & + & $0.51^{* * *}$ \\
\hline HR and Customer \& Supplier practices & + & $0.25^{* *}$ \\
\hline \multicolumn{3}{|c|}{$\begin{array}{ll} & \text { Three dimensions } \\
\end{array}$} \\
\hline Green, HR, and Customer \& Supplier practices & + & $0.43 * * *$ \\
\hline
\end{tabular}

The reference is the case where no dimension is implemented.

$(*),(* *),(* * *)$ indicate parameter significance at the 10,5 and 1 per cent level, respectively.

(ns) indicates Non Significant.

Table 3: Quantitative estimations

\begin{tabular}{|l|l|l|}
\hline Number of Dimensions & Sign & Coeffcient \\
\hline 1 CSR dimension & ns & 0.45 \\
\hline 2 CSR dimensions & + & $0.26 * *$ \\
\hline 3 CSR dimensions & + & $0.43 * * *$ \\
\hline
\end{tabular}

The reference is the case where no dimension is implemented.

$(*),(* *),(* * *)$ indicate parameter significance at the 10,5 and 1 per cent level, respectively.

(ns) indicates Non Significant. 


\section{Isolated Effect of CSR Dimensions}

From Table 2 we observe that compared to the case where no dimension is implemented, having a green practice has a positive effect on profit per employee. The findings are consistent with previous studies (e.g. Lo et al., 2012) showing that improvement of a firm's performance is one of the main triggers of a firm's decision to invest in environmental practices. Moreover, we obtain similar results concerning the effect of HR practices on a firm's profitability, which confirms previous findings (e.g. Huselid, 1995). Once again, the customer \& supplier dimension has a positive effect on a firm's profit which is in line with previous findings (Yeung, 2008; Pekovic and Rolland, 2013). Therefore, we may conclude that our Hypothesis 1A is confirmed since green, human resources and customer \& supplier dimensions of CSR in isolation exert a positive impact on a firm's profit. It is worth noting that the customer \& supplier dimension exerts a weaker effect compared to the other two dimensions (coefficient $=0.30 ;$ p-value $<0.067$ ) which suggests that highly demanding practices implemented in isolation and not as part of coherent management practices bundle may be less beneficial for a firm's profit growth. In other words, the different dimensions of CSR influence a firm's profitability differently, which is in the line with previous studies (e.g. Barcos et al., 2013; Brammer and Milligton, 2008; Mackey et al., 2007). Our results confirm those of Barnett and Salomon (2006) which indicate that the effects of CSR vary in their intensity. Therefore, using a single specific dimension of CSR when examining its relationship with firm performance does not show the "complete" picture in term of intensity of effect. In this sense, our results are also consistent with studies showing that firms with better ESG performance tend to face significantly lower capital constraints, and that the relation is primarily driven by social and environmental performance (El Ghoul et al., 2011).

\section{The CSR Dimensions are Positively Correlated but are Substitutables}


Let us turn now to the interaction between each CSR dimension. One can note that all interactions are positive (Table 2). However, their levels of intensity vary according to the type of interaction considered. A positive interaction between some dimensions does not necessarily lead to a complementarity or substitutability between these dimensions. More precisely, when testing for complementarity and substitutability effects, we observe that all dimensions are substitutes to each other. Let take the example of green and customer \& supplier dimensions. They are substitutes (in the sense of Athey and Stern 1998) because the coefficient associated with the pattern "green and customer \& supplier practices" is 0.51 , which is weaker than the sum of their isolated effects, which is 0.83 (the coefficient associated with the pattern "green practices only" is 0.53 and the coefficient associated with the pattern "customer \& supplier practices only" is 0.30 ). Therefore, we confirm Hypothesis 2 on substitutable CSR dimensions. However, there is one point of divergence. Hypothesis 2 predicts also the complementarity effect between HR and customer \& supplier dimensions, while the empirical results indicate a substitution effect. Thus, we may conclude that the HR dimension shares some common characteristics with the customer \& supplier dimension, which induces substitution between those dimensions rather than complementarity. The Stakeholder theory is only partially supported here, in the sense that the primary stakeholders are substitutes (employees, customers \& suppliers). The environment appears as a nonprimary stakeholder relatively substitutable to primary stakeholders from a CSR perspective, with a similar kind of result that was found in Cavaco and Crifo (2013).

\section{The Implementation of CSR Practices: a Path-dependent Process}

Let us now analyze the magnitudinal effect for moving from one configuration of dimension(s) to another. We ask whether a firm starting with a certain configuration can perform better (in terms of profit) by adding or removing some dimension(s). Only one 
configuration fulfills this requirement: green and HR. The interpretation is that when a firm starts with this configuration then it is better not to move to another configuration. In all other configurations, firms can always improve their profits either by adding or removing some dimensions. So from the point of view of their effects on firm performance, the green and HR can be considered as "optimal". Two remarks can be made from these results. Firstly, they show that substitutability does not necessarily lead to overall inefficiency. In our cases, the green and HR dimensions are clearly substitutes. Secondly, our results suggest that the implementation of CSR dimensions by firms is a path-dependent process. That is, the CSR configuration that is in place within firms is the result of their successive past choices of CSR dimensions, in particular at the starting point. In other words, most firms seem to use an adaptative implementation process instead of a purely rational calculus of the best configurations. Indeed, the "optimal" solution is not implemented by all firms.

\section{Aggregated Effect of CSR Dimensions and the Quality-Quantity Trade-off}

From Table 3, we observe that our aggregate measure of CSR, which counts quantitatively the number of practices adopted in terms of environmental, human resources, and customers \& suppliers practices, affects positively and significantly firm performance when a firm implements at least two dimensions of CSR. The estimates clearly show that the more the dimensions are used by firms, the higher the effects on their economic performance. This suggests that a purely quantitative strategy consisting of accumulating CSR dimensions works and that Hypothesis 1B, indicating that an aggregate measure of CSR is positively associated with firm performance, is fulfilled. However the comparison of the coefficients in Table 2 and Table 3 suggests that a quantitative strategy is less efficient than a qualitative one. For instance over the seven possible qualitative policies, four provide better results than the best quantitative policy. The choice of interaction of CSR dimensions matter for a firm's profit. In 
this sense, firms that want to achieve business performance improvement through investment in CSR dimensions need to achieve a best "fit" between the types of CSR dimensions that they implement (e.g. Brammer and Pavelin, 2006). Additionally, as suggested by Mackey et al. (2007), Brammer and Milligton (2008) and Barcoset al. (2013), our findings confirm that at least some (specific) forms of CSR (in our case, for instance green and customer \& supplier) improve firm performance more than others (in our case, for instance HR and customer \& supplier). To conclude, the profitability of CSR investments in French firms seems to rely on a specific qualitative mix of different CSR dimensions rather than a pure quantitative approach accumulating practices without designing a consistent set of interactions among them.

\section{CONCLUSION}

To date, the extensive and growing theoretical and empirical research has identified no clear pattern in the relationship between CSR and firm performance (Brummer, 1991; McWilliams and Siegel, 1997; Waddock and Graves, 1997; McWilliams and Siegel, 2001). Generally, the literature argues that one of the main reasons for this absence of consensus is associated with measurement problems (e.g. Surocca et al., 2010). Given this concern, we perform, using secondary data, a quantity-quality trade-off analysis between the various dimensions of Corporate Social Responsibility in order to provide a richer conceptualization and understanding concerning the relationship between CSR and firm performance. Hence, using secondary data brings another dimension in the CSR research field and may allow for a wider generalization of conclusions. For this purpose, we first examine the impact of stakeholders CSR components separately (environmental performance, HR performance, customer \& supplier performance), which permits to us to understand how CSR measures in isolation 
impact on a firm's profitability. Even though our findings indicate that different dimensions of CSR have significant and positive effects on firm performance, the intensity of such effects is not the same across different dimensions. Second, we create an aggregate measure of the CSR indicator based on our three CSR dimensions. We observe that the aggregate measure of CSR positively and significantly affects firm performance. Third, we study how the interactions between different CSR dimensions affect corporate performance. We show that all forms of CSR are associated with a positive significant coefficient. When testing for complementarity or substitutability of the dimensions, we observe only substitutability. In sum, while our findings are consistent with those supporting a positive relationship between CSR and firm profitability (e.g. Cochran and Wood, 1984; Turban and Greening; 1996; Waddock and Graves, 1997; McWilliams and Siegel, 2001; Godfrey, 2004), additional analysis confirms McWilliams and Siegel's argument (2000) indicating that their relationship is very complex. Our findings suggest two sources of complexity: (1) the CSR and firm performance relationship is not homogeneous in terms of intensity when examining different dimensions of CSR; (2) the interaction among different CSR dimensions produces different effects on firm performance, but only in terms of effect intensity.

Our findings have important implications for policy-makers. They suggest that managers need to be careful in choosing appropriate CSR tasks since those dimensions need to be compatible with each other and with a firm's overall strategy. Therefore, the question for managers is not simply whether to invest in social responsibility; it is rather what form of social responsibility is suitable for a specific firm's strategy. Additionally, the results suggest that different forms of firm social orientation are not only beneficial for social improvements, but could be considered as a tool for firm performance improvement.

This study has limitations that could be addressed in future work. First, our approach relies on the nature of the data available to measure each dimension. For instance, the environmental 
component is captured through one variable only (unlike the HR or the customer \& supplier components), and the governance dimension is not measured due to the lack of information. Second, we work on a sample of French firms, which suggests that the ability to generalize the results is limited since there are important international institutional differences in the implementation of socially responsible practices. Third, future research could test the effect of CSR practices on employee outcomes given that the literature covering this issue is quite limited for the moment. Only anecdotal evidences exists which supports the argument of greater employee loyalty and productivity at environmentally or socially-responsible firms. Finally, recent research suggests that the debate concerning CSR and firm performance should be taken further by including additional intermediate variables that can improve our understanding of the processes through which CSR influences firm outcomes (e.g. Delmas and Pekovic, 2013; Gallear, Ghobadian, Chen, 2012; Surroca et al., 2010). For instance, Surocca et al. (2010) propose a model in which firm-based intangible resources, including innovation, human resources, reputation, and organizational culture, are mediator variables between CSR and firm performance. Therefore, future research should examine indirect mechanisms through which CSR influences firm performance.

\section{REFERENCES}

Athey S., Stern S. 1998. An Empirical Framework for Testing Theories About Complementarity in Organizational Design. NBER Working Paper, 6600.

Barla P. 2007.ISO 14001 certification and environmental performance in Quebec's pulp and paper industry. Journal of Environmental Economics and Management53(3): 291-306. 
Barnett M.L., Salomon R.M. 2006. Beyond Dichotomy: The Curvilinear Relationship between Social Responsibility and Financial Performance. Strategic Management Journal27(11): 1101-1122.

Barcos L., Barroso A.,Surroca J.,Tribo J. 2013. Corporate social responsibility and inventory policy. International Journal of Production Economics143: 580-588

Baumeister R.F., Bratslavsky, E. Finkenauer C., Vohs K.D. 2001. Bad is stronger than good. Review of General Psychology 5: 323-370.

Berens G., Riel, C.B.M., Rekom J. 2007. The CSR-quality trade-off: when can corporate social responsibility and corporate ability compensate each other? Journal of Business Ethics74: 233-252.

Bernard B.A., Eaton J., Jensen B., Kortum S. 2003. Plants and productivity in international trade. Econometrica 93 (4): 1268-1290.

Brammer S.J., Pavelin S. 2006. Corporate Reputation and Social Performance: The Importance of Fit. Journal of Management Studies 43(3): 435-455.

Brammer S., Millington A. 2008. Does it pay to be different? An analysis of the relationship between corporate social and financial performance. Strategic Management Journal 29 (12): $1325-1343$.

Brummer J.J. 1991. Corporate Responsibility and Legitimacy: An Interdisciplinary Analysis. New York, Greenwood Press.

Capon N., Farley J.U., Hoenig S. 1990. Determinants of financial performance: A metaanalysis. Management Science 36: 1143-1159.

Cavaco S., Crifo P. 2013. The CSR-performance missing link: complementarity between environmental, social and business behaviors criteria? Working Paper EcolePolytechnique $\mathrm{n}^{\circ}$ 2013-07. 
Chatterji A., Levine, D., Toffel, M. 2009. How Well Do Social Ratings Actually Measure Corporate Social Responsibility? Journal of Economics \& Management Strategy 18 (1): 125169.

Chen C-M., Delmas M. 2011.Measuring Corporate Social Responsibility: An Efficiency Perspective. Production and Operations Management20(6): 789-804.

Cochran P.L., Wood R.A. 1984. Corporate social responsibility and financial performance. The Academy of Management Journal 27(1): 42-56.

Delmas M., Pekovic S. 2013. Environmental Standards and Labor Productivity: Understanding the Mechanisms that Sustain Sustainability, Journal Of Organizational Behavior, 34 (2): 230-252.

Delmas M., Montiel I. 2009.Greening the Supply Chain: When is Customer Pressure Effective? Journal of Economics and Management Strategy 18 (1): 171-201.

El Ghoul S., Guedamin O., Kwok C.C., Mishra D.R. 2011. Does corporate social responsibility affect the cost of capital ? Journal of Banking and Finance 35 (9): 2388-2406. European Commission 2001. Promoting a European Framework for Corporate Social Responsibility. Commission Green paper COM (2001) 366 Final.

Fernandez-Kranz D., Santalo J. 2010. When Necessity Becomes a Virtue: The Effect of Product Market Competition on Corporate Social Responsibility, Journal of Economics \& Management Strategy 19(2): 453-487.

Ferrell O. 2004. Business ethics and customer stakeholders. Academy of Management Executive 18 (2): 126-129.

Filbeck G., Gorman R.F. 2004. The Relationship Between the Environmental and Financial Performance of Public Utilities. Environmental and Resource Economics 29: 137-157.

Friedman M. 1970. The social responsibility of business is to increase its profits. New York Times Magazine, 13 September: 122-126. 
Gallear D., Ghobadian A., Chen W. 2012. Corporate responsibility, supply chain partnership and performance: An empirical examination. International Journal of Production Economics 140: $83-91$.

Ghauri P., Gronhaug K. 2005. Research Methods in business Studies, 3ed. PrenticeHall.

Giménez C., Sierra V., Rodon, J. 2012. Sustainable operations: Their impact on the triple bottom line. International Journal of Production Economics, 140 (1): 149-159.

Godfrey P.C. 2004. The relationship between corporate philanthropy and shareholder wealth: A risk management perspective. Academy of Management Review 30: 777-798.

Grabisch M. 1997. k-order additive discrete fuzzy measures and their representation. Fuzzy Sets and Systems 92: 167-189.

Gray W., Shadbegian R. 2003. Plant vintage, technology, and environmental regulation. Journal of Environmental Economics and Management 46: 384-402.

Griliches Z. 1979. Issues in Assessing the Contribution of Research and Development to Productivity Growth. The Bell Journal of Economies10(1): 92-116.

Grolleau G., Mzoughi N., Pekovic S. 2007. Chemical Firms' Registration for the Responsible Care Program and the ISO 14001 Standard: A Comparative Approach. Economics Bulletin 12: $1-13$.

Hillman A., Keim G. 2001. Shareholder value, stakeholder management, and social issues: what's the bottom line? Strategic Management Journal, 22: 125-139.

Hart S.L. 1995. A natural resource-based view of the firm. Academy of Management Review 20(4): 986-1014.

Hull C.E., Rothenberg S. 2008. Firm performance: the interactions of corporate social performance with innovation and industry differentiation. Strategic Management Journal 29: 781-789. 
Huselid M. 1995. The Impact of Human Resource Management Practices on Turnover, Productivity, and Corporate Financial Performance, Academy of Management Journal, 38: 635-672.

Ichniowski C., Shaw K., Prennushi G. 1997. The Effects of Human Resource Management on Productivity. American Economic Review87: 291-31.

Lehtonen M. 2004. The environmental-social interface of sustainable development: capabilities, social capital, institutions. Ecological Economics 49 (2): 199-214.

Lin C., Chow W., Madu C.N., Kuei, C.H. and Yu P.P., 2005. A structural equation model of supply chain quality management and organizational performance. International Journal of Production Economics, 96 (3): 355-365.

Lo C.K.Y., Yeung A.C.L., Cheng T.C.E. 2012. The impact of environmental management systems on financial performance in fashion and textiles industries. International Journal of Production Economics, 135 (2): 561-567.

Mackey A., Mackey T.B., Barney J.B. 2007. Corporate social responsibility and firm performance: Investor preferences and corporate strategies. Academy of Management Review 32: $817-835$.

Maddala G.S. 1983. Limited-Dependent and Qualitative Variables in Econometrics. Cambridge University Press.

Margolis J., Elfenbein H., Walsh J. 2009. Does it pay to be good? A meta-analysis and direction of research on the relationship between corporate social and financial performance. Harvard University Working Paper.

Margolis J., Walsh J. 2003. Misery loves companies: rethinking social initiatives by business, Administrative Science Quarterly 48: 268-305.

McWilliams A., Siegel D. 1997. Event Studies in Management Research: Theoretical and Empirical issues. Academy of Management Journal 40 (3): 626-657. 
McWilliams A., Siegel D. 2000. Corporate social responsibility and financial performance: correlation or misspecification? Strategic Management Journal 21 (5): 603-609.

McWilliams A., Siegel D. 2001. Corporate social responsibility: a theory of the firm Perspective. The Academy of Management Review 26 (1): 117-127.

McWilliams A., Siegel D.S., Wright, P.M. 2006. Corporate Social Responsibility: Strategic Implications. Journal of Management Studies 43 (1): 1-18.

Milgrom P., Roberts J. 1990. The Economics of Modern Manufacturing: Technology, Strategy, and Organization. American Economic Review 80: 511-528.

Miller D.K, Bromiley P. 1990. Strategic Risk and Corporate Performance: An Analysis of Alternative Risk Measures. The Academy of Management Journal 33 (4): 756-779.Orlitzky, M., Schmidt, F., Rynes, S. 2003. Corporate social and financial performance: a meta-analysis, Organization Studies 24 (3): 403-441.

Orlitzky M., Benjamin J.D. 2001. Corporate social performance and firm risk: A metaanalytic review. Business and Society 40 (4): 369-396.

Pekovic S. 2010. The Determinants of ISO 9000 Certification: A Comparison of the Manufacturing and Service Sectors. Journal of Economic Issues 44 (4): 895-914.

Pekovic S., Rolland S. 2012. L'impact de l'orientation client sur la performance des entreprises françaises: étude empirique des effets directs et modérateurs. Recherche et Applications en Marketing 27(4): 11-28

Reitzig M.G., Wagner S. 2010. The hidden costs of outsourcing: Evidence from patent data. Strategic Management Journal 31 (11): 1183-1201.

Robbins D.K., Pearce J.A. 1992. Turnaround: Retrenchment and recovery. Strategic Management Journal 13: 287-309.

Roodman D. 2009. Estimating fully observed recursive mixed-process models with cmp. Center for Global Development Working Paper 168. 
Russo M.V., Fouts P.A. 1997. A Resource Based Perspective on Corporate Environmental Performance and Profitability. Academy of Management Journal 40 (3): 534-559.

Surroca J., Tribò J.A., Waddock S. 2010. Corporate Responsibility and Financial Performance: the Role of Intangible Resources. Strategic Management Journal 31 (5): 463490.

Turban D.B., Greening D.W. 1997. Corporate social performance and organizational attractiveness to prospective employees. The Academy of Management Journal 40 (3): 658672.

Utting P. 2005. Rethinking Business Regulation: From Self-Regulation to Social Control. Paper no. 15, Technology, Business and Society Programme, UN Research Institute for Social Development.

Waddock S.A., Graves S.B. 1997. The corporate social performance-financial performance link. Strategic Management Journal 18 (4): 303-310.

Whittington R., Pettigrew A., Peck S., Fenton E. and Canyon M. 1999. Change and Complementarities in the New Competitive Landscape: A European Panel Study, 1992-1996. Organization Science 10: 583-600.

Wright M.P., Kehoe, R.R. 2008. Human resource practices and organizational commitment: A deeper examination, Asia Pacific Journal of Human Resources 46 (1): 6-20.

Yeung A.C.L. 2008. Strategic supply management, quality initiatives, and organizational performance. Journal of Operations Management 26: 490-502.

Zhu Z., Nakata C. 2007. Reexamining the link between customer orientation and business performance: The role of information systems. Journal of Marketing Theory \& Practice $\mathbf{1 5}$ (3): 187-203. 


\section{Appendix 1}

Table B: Simultaneous Equations Model estimates of the relation between interaction of CSR dimensions and profit

\begin{tabular}{|c|c|c|c|c|c|c|c|c|c|c|c|c|c|c|}
\hline Variables & Green only & Profit & HR only & Profit & C\&S only & Profit & $\begin{array}{l}\text { Green } \\
\text { and HR }\end{array}$ & Profit & $\begin{array}{l}\text { Green } \\
\text { and } C \& S\end{array}$ & Profit & $\begin{array}{l}\mathrm{HR} \text { and } \\
\mathrm{C} \& S\end{array}$ & Profit & $\begin{array}{l}\text { All } \\
\text { dimensions }\end{array}$ & Profit \\
\hline $\begin{array}{l}\text { Interactions of CSR } \\
\text { dimensions }\end{array}$ & & $\begin{array}{l}0.53 * * * \\
(0.24)\end{array}$ & & $\begin{array}{l}0.52^{* * *} \\
(0.15)\end{array}$ & & $\begin{array}{l}0.30^{*} \\
(0.16)\end{array}$ & & $\begin{array}{l}0.59^{*} \\
(0.32)\end{array}$ & & $\begin{array}{l}0.51 * * * \\
(0.19)\end{array}$ & & $\begin{array}{l}0.25^{* * *} \\
(0.10)\end{array}$ & & $\begin{array}{l}0.43 * * * \\
(0.11)\end{array}$ \\
\hline Hard law & $\begin{array}{l}0.13^{*} \\
(0.07)\end{array}$ & & $\begin{array}{l}0.15 * * * \\
(0.04)\end{array}$ & & $\begin{array}{l}0.11 * * * \\
(0.04)\end{array}$ & & $\begin{array}{l}0.25 * * * \\
(0.11)\end{array}$ & & $\begin{array}{l}0.10 \\
(0.06)\end{array}$ & & $\begin{array}{l}0.21 * * * \\
(0.04)\end{array}$ & & $\begin{array}{l}0.29 * * * \\
(0.07)\end{array}$ & \\
\hline Group tool & $\begin{array}{l}0.18 \\
(0.14)\end{array}$ & & $\begin{array}{l}0.44 * * * \\
(0.07)\end{array}$ & & $\begin{array}{l}0.37 * * * \\
(0.07)\end{array}$ & & $\begin{array}{l}0.55 * * * \\
(0.15)\end{array}$ & & $\begin{array}{l}0.68 * * * \\
(0.09)\end{array}$ & & $\begin{array}{l}0.76 * * * \\
(0.06)\end{array}$ & & $\begin{array}{l}1.02 * * * \\
(0.08)\end{array}$ & \\
\hline Size & $\begin{array}{l}0.00 * * * \\
(0.00)\end{array}$ & $\begin{array}{l}-0.00 * * * \\
(0.00)\end{array}$ & $\begin{array}{l}0.00 * * * \\
(0.00)\end{array}$ & $\begin{array}{l}-0.00 * * \\
(0.00)\end{array}$ & $\begin{array}{l}0.00 * * * \\
(0.00)\end{array}$ & $\begin{array}{l}-0.00 * * * \\
(0.00)\end{array}$ & $\begin{array}{l}0.00 * * * \\
(0.00)\end{array}$ & $\begin{array}{l}-0.00 * * \\
(0.00)\end{array}$ & $\begin{array}{l}0.00 * * * \\
(0.00)\end{array}$ & $\begin{array}{l}-0.00 * * * \\
(0.00)\end{array}$ & $\begin{array}{l}0.00 * * * \\
(0.00)\end{array}$ & $\begin{array}{l}-0.00 * * * \\
(0.00)\end{array}$ & $\begin{array}{l}0.00 * * * \\
(0.00)\end{array}$ & $\begin{array}{l}0.00 \\
(0.00)\end{array}$ \\
\hline Holding & $\begin{array}{l}0.04 \\
(0.08)\end{array}$ & $\begin{array}{l}0.37 * * * \\
(0.05)\end{array}$ & $\begin{array}{l}0.25 * * * \\
(0.04)\end{array}$ & $\begin{array}{l}0.33 * * * \\
(0.05)\end{array}$ & $\begin{array}{l}0.39 * * * \\
(0.04)\end{array}$ & $\begin{array}{l}0.36 * * * \\
(0.05)\end{array}$ & $\begin{array}{l}0.17 \\
(0.10)\end{array}$ & $\begin{array}{l}0.37 * * * \\
(0.05)\end{array}$ & $\begin{array}{l}0.31 * * * \\
(0.07)\end{array}$ & $\begin{array}{l}0.35 * * * \\
(0.05)\end{array}$ & $\begin{array}{l}0.64 * * * \\
(0.04)\end{array}$ & $\begin{array}{l}0.32 * * * \\
(0.05)\end{array}$ & $\begin{array}{l}0.55 * * * \\
(0.07)\end{array}$ & $\begin{array}{l}0.34 * * * \\
(0.05)\end{array}$ \\
\hline Uncertainty & $\begin{array}{l}0.10 \\
(0.08)\end{array}$ & $\begin{array}{l}-0.18 * * * \\
(0.04)\end{array}$ & $\begin{array}{l}0.02 \\
(0.04)\end{array}$ & $\begin{array}{l}-0.18 * * * \\
(0.04)\end{array}$ & $\begin{array}{l}0.05 \\
(0.04)\end{array}$ & $\begin{array}{l}-0.21 * * * \\
(0.04)\end{array}$ & $\begin{array}{l}0.06 \\
(0.11)\end{array}$ & $\begin{array}{l}-0.19 * * * \\
(0.04)\end{array}$ & $\begin{array}{l}-0.04 \\
(0.07)\end{array}$ & $\begin{array}{l}-0.18 * * * \\
(0.04)\end{array}$ & $\begin{array}{l}0.17 * * * \\
(0.04)\end{array}$ & $\begin{array}{l}-0.17 * * * \\
(0.04)\end{array}$ & $\begin{array}{l}0.04 \\
(0.07) \\
\end{array}$ & $\begin{array}{l}-0.16 * * * \\
(0.04)\end{array}$ \\
\hline Market down & $\begin{array}{l}-0.01 \\
(0.09)\end{array}$ & $\begin{array}{l}-0.26^{* * *} \\
(0.05)\end{array}$ & $\begin{array}{l}-0.05 \\
(0.05)\end{array}$ & $\begin{array}{l}-0.29 * * * \\
(0.05)\end{array}$ & $\begin{array}{l}-0.01 \\
(0.05)\end{array}$ & $\begin{array}{l}-0.24 * * * \\
(0.05)\end{array}$ & $\begin{array}{l}0.04 \\
(0.13)\end{array}$ & $\begin{array}{l}-0.24 * * * \\
(0.05)\end{array}$ & $\begin{array}{l}-0.04 \\
(0.08)\end{array}$ & $\begin{array}{l}-0.24 * * * \\
(0.05)\end{array}$ & $\begin{array}{l}-0.05 \\
(0.05)\end{array}$ & $\begin{array}{l}-0.18 * * * \\
(0.05)\end{array}$ & $\begin{array}{l}-0.10 \\
(0.08)\end{array}$ & $\begin{array}{l}-0.25 * * * \\
(0.05)\end{array}$ \\
\hline Growing Market & $\begin{array}{l}-0.02 \\
(0.10)\end{array}$ & $\begin{array}{l}0.17 * * * \\
(0.05)\end{array}$ & $\begin{array}{l}0.16^{* * * *} \\
(0.05)\end{array}$ & $\begin{array}{l}0.15^{* * * *} \\
(0.05)\end{array}$ & $\begin{array}{l}0.20 * * * \\
(0.05)\end{array}$ & $\begin{array}{l}0.16^{* * * *} \\
(0.05)\end{array}$ & $\begin{array}{l}0.19 \\
(0.13)\end{array}$ & $\begin{array}{l}0.14 * * \\
(0.06)\end{array}$ & $\begin{array}{l}-0.12 \\
(0.09)\end{array}$ & $\begin{array}{l}0.14 * * * \\
(0.05)\end{array}$ & $\begin{array}{l}0.13 * * \\
(0.05)\end{array}$ & $\begin{array}{l}0.21 * * * \\
(0.05)\end{array}$ & $\begin{array}{l}0.08 \\
(0.08)\end{array}$ & $\begin{array}{l}0.16^{* * * *} \\
(0.05)\end{array}$ \\
\hline Export & $\begin{array}{l}0.26 \\
(0.23)\end{array}$ & $\begin{array}{l}0.96 \text { **** } \\
(0.17)\end{array}$ & $\begin{array}{l}0.202 \\
(0.13)\end{array}$ & $\begin{array}{l}1.07 * * * \\
(0.15)\end{array}$ & $\begin{array}{l}0.17 \\
(0.12)\end{array}$ & $\begin{array}{l}0.94 * * * \\
(0.14)\end{array}$ & $\begin{array}{l}0.67 * * * \\
(0.25)\end{array}$ & $\begin{array}{l}1.02 * * * \\
(0.17)\end{array}$ & $\begin{array}{l}0.22 \\
(0.16)\end{array}$ & $\begin{array}{l}0.94 * * * \\
(0.15)\end{array}$ & $\begin{array}{l}0.18 \\
(0.12)\end{array}$ & $\begin{array}{l}1.06^{* * * *} \\
(0.12)\end{array}$ & $\begin{array}{l}0.41 * * * \\
(0.15)\end{array}$ & $\begin{array}{l}0.94 * * * \\
(0.14)\end{array}$ \\
\hline R\&D & $\begin{array}{l}0.07 \\
(0.12)\end{array}$ & $\begin{array}{l}0.12 \\
(0.08)\end{array}$ & $\begin{array}{l}0.27 * * * \\
(0.06)\end{array}$ & $\begin{array}{l}0.09 \\
(0.07)\end{array}$ & $\begin{array}{l}0.49 * * * \\
(0.05)\end{array}$ & $\begin{array}{l}0.20 * * * \\
(0.07)\end{array}$ & $\begin{array}{l}0.23 \\
(0.15)\end{array}$ & $\begin{array}{l}0.08 \\
(0.08)\end{array}$ & $\begin{array}{l}0.62 * * * \\
(0.08)\end{array}$ & $\begin{array}{l}0.07 \\
(0.08)\end{array}$ & $\begin{array}{l}0.63 * * * \\
(0.05)\end{array}$ & $\begin{array}{l}0.25 * * * \\
(0.06)\end{array}$ & $\begin{array}{l}0.88 * * * \\
(0.07)\end{array}$ & $\begin{array}{l}0.14 * * \\
(0.07)\end{array}$ \\
\hline Advertising & $\begin{array}{l}0.14^{*} \\
(0.08)\end{array}$ & $\begin{array}{l}0.17 * * * \\
(0.04)\end{array}$ & $\begin{array}{l}0.36^{* * *} \\
(0.05)\end{array}$ & $\begin{array}{l}0.14 * * * \\
(0.04)\end{array}$ & $\begin{array}{l}0.46 * * * \\
(0.05)\end{array}$ & $\begin{array}{l}0.14 * * * \\
(0.04)\end{array}$ & $\begin{array}{l}0.57 * * * \\
(0.17)\end{array}$ & $\begin{array}{l}0.15^{* * * *} \\
(0.04)\end{array}$ & $\begin{array}{l}0.249 * * * \\
(0.08)\end{array}$ & $\begin{array}{l}0.14 * * * \\
(0.04)\end{array}$ & $\begin{array}{l}0.87 * * * \\
(0.06)\end{array}$ & $\begin{array}{l}0.14 * * * \\
(0.04)\end{array}$ & $\begin{array}{l}0.72 * * * \\
(0.10)\end{array}$ & $\begin{array}{l}0.13 * * * \\
(0.04)\end{array}$ \\
\hline Consumption goods & $\begin{array}{l}-0.25 \\
(0.21)\end{array}$ & $\begin{array}{l}-0.19 \\
(0.12)\end{array}$ & $\begin{array}{l}0.03 \\
(.11)\end{array}$ & $\begin{array}{l}-0.16 \\
(0.11)\end{array}$ & $\begin{array}{l}-0.50 * * * \\
(0.10)\end{array}$ & $\begin{array}{l}-0.06 \\
(0.11)\end{array}$ & $\begin{array}{l}-0.75^{*} \\
(0.38)\end{array}$ & $\begin{array}{l}-0.23^{*} \\
(0.13)\end{array}$ & $\begin{array}{l}-0.77 * * * \\
(0.20)\end{array}$ & $\begin{array}{l}-0.21^{*} \\
(0.12)\end{array}$ & $\begin{array}{l}-0.55^{* * *} \\
(0.11)\end{array}$ & $\begin{array}{l}-0.10 \\
(0.10)\end{array}$ & $\begin{array}{l}-0.68 * * * \\
(0.17)\end{array}$ & $\begin{array}{l}-0.14 \\
(0.11)\end{array}$ \\
\hline Equipment goods & $\begin{array}{l}-0.83^{* *} \\
(0.37)\end{array}$ & $\begin{array}{l}-0.20^{*} \\
(0.12)\end{array}$ & $\begin{array}{l}0.06 \\
(0.12)\end{array}$ & $\begin{array}{l}-0.20 * * * \\
(0.11)\end{array}$ & $\begin{array}{l}0.10 \\
(0.09)\end{array}$ & $\begin{array}{l}-0.20 \text { *** } \\
(0.09)\end{array}$ & $\begin{array}{l}-0.15 \\
(0.23)\end{array}$ & $\begin{array}{l}-0.25 * * \\
(0.12)\end{array}$ & $\begin{array}{l}0.06 \\
(0.13)\end{array}$ & $\begin{array}{l}-0.21 * * * \\
(0.11)\end{array}$ & $\begin{array}{l}-0.08 \\
(0.10)\end{array}$ & $\begin{array}{l}-0.18 * * \\
(0.09)\end{array}$ & $\begin{array}{l}-0.30 * * * \\
(0.13)\end{array}$ & $\begin{array}{l}-0.25 * * * \\
(0.10)\end{array}$ \\
\hline Sales & $\begin{array}{l}0.11 \\
(0.13)\end{array}$ & $\begin{array}{l}0.07 \\
(0.08)\end{array}$ & $\begin{array}{l}0.11 \\
(0.08)\end{array}$ & $\begin{array}{l}0.12 \\
(0.07)\end{array}$ & $\begin{array}{l}-0.37 * * * \\
(0.07)\end{array}$ & $\begin{array}{l}0.13 * \\
(0.07)\end{array}$ & $\begin{array}{l}0.14 \\
(0.18)\end{array}$ & $\begin{array}{l}0.06 \\
(0.08)\end{array}$ & $\begin{array}{l}-0.33 * * * \\
(0.10)\end{array}$ & $\begin{array}{l}0.07 \\
(0.08)\end{array}$ & $\begin{array}{l}-0.23 * * * \\
(0.07)\end{array}$ & $\begin{array}{l}0.12 * \\
(0.06)\end{array}$ & $\begin{array}{l}-0.31 * * * \\
(0.09)\end{array}$ & $\begin{array}{l}0.09 \\
(0.07)\end{array}$ \\
\hline Construction & $\begin{array}{l}-0.02 \\
(0.16)\end{array}$ & $\begin{array}{l}-0.43 * * * \\
(0.08)\end{array}$ & $\begin{array}{l}-0.07 \\
(0.10)\end{array}$ & $\begin{array}{l}-0.41^{* * *} \\
(0.08)\end{array}$ & $\begin{array}{l}-0.05 \\
(0.08)\end{array}$ & $\begin{array}{l}-0.42 * * * \\
(0.07)\end{array}$ & $\begin{array}{l}-0.22 \\
(0.25)\end{array}$ & $\begin{array}{l}-0.44 * * * \\
(0.08)\end{array}$ & $\begin{array}{l}-0.32 * * \\
(0.13)\end{array}$ & $\begin{array}{l}-0.43 * * * \\
(0.08)\end{array}$ & $\begin{array}{l}-0.24 * * * \\
(0.09)\end{array}$ & $\begin{array}{l}-0.34 * * * \\
(0.07)\end{array}$ & $\begin{array}{l}-0.34 * * * \\
(0.12)\end{array}$ & $\begin{array}{l}-0.41^{* * * *} \\
(0.08)\end{array}$ \\
\hline Finance and real estate & -0.13 & $0.03 *$ & $0.36 * * *$ & $0.20 *$ & $-0.59 * * *$ & $0.16^{*}$ & -0.34 & 0.04 & $-0.65 * * *$ & 0.05 & $-0.42 * * *$ & $0.28 * * *$ & $-0.92 * * *$ & 0.08 \\
\hline
\end{tabular}




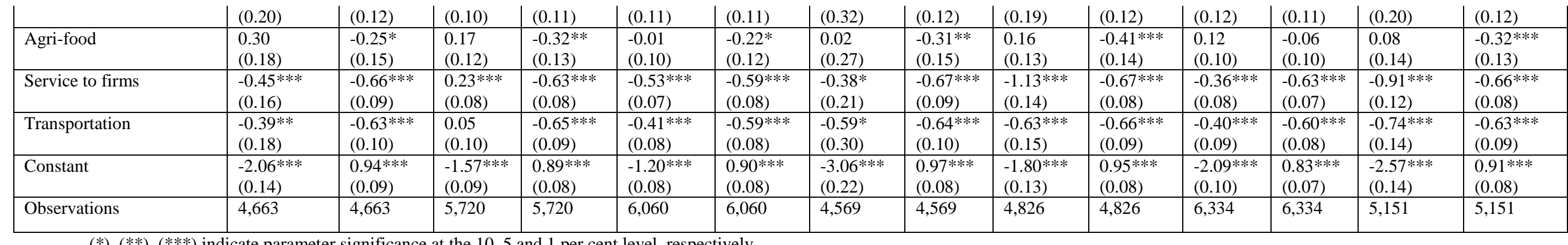

$(*),(* *),(* * *)$ indicate parameter significance at the 10,5 and 1 per cent level, respectively. 


\section{Appendix 1}

Table A: Simultaneous Equations Model estimates of the relation between aggregate measure of CSR dimensions and profit

\begin{tabular}{|c|c|c|c|c|c|c|}
\hline Variable & $\begin{array}{l}\text { One dimension } \\
\text { (versus no } \\
\text { dimension) }\end{array}$ & Profit & $\begin{array}{l}\text { Two } \\
\text { dimensions } \\
\text { (versus no } \\
\text { dimension) }\end{array}$ & Profit & $\begin{array}{l}\text { Three } \\
\text { dimensions } \\
\text { (versus no } \\
\text { dimension) }\end{array}$ & Profit \\
\hline $\begin{array}{l}\text { Aggregate measure of } \\
\text { CSR dimensions }\end{array}$ & & $\begin{array}{c}0.45 \\
(0.35) \\
\end{array}$ & & $\begin{array}{c}0.26 * * \\
(0.10)\end{array}$ & & $\begin{array}{c}0.43 * * * \\
(0.11)\end{array}$ \\
\hline Hard law & $\begin{array}{c}0.14 * * * \\
(0.03)\end{array}$ & & $\begin{array}{c}0.120 * * * \\
(0.04)\end{array}$ & & $\begin{array}{c}0.29 * * * \\
(0.07)\end{array}$ & \\
\hline Group tool & $\begin{array}{l}0.41 * * * \\
(0.07)\end{array}$ & & $\begin{array}{c}0.76 * * * \\
(0.06)\end{array}$ & & $\begin{array}{c}1.025 * * * \\
(0.08)\end{array}$ & \\
\hline Size & $\begin{array}{c}0.00 * * * \\
(0.00)\end{array}$ & $\begin{array}{c}-0.00 * * * \\
(0.00)\end{array}$ & $\begin{array}{c}0.00 * * * \\
(0.00)\end{array}$ & $\begin{array}{c}-0.00 * * * \\
(0.00)\end{array}$ & $\begin{array}{c}0.00 * * * \\
(0.00)\end{array}$ & $\begin{array}{c}0.00 \\
(0.00)\end{array}$ \\
\hline Holding & $\begin{array}{c}0.33 * * * \\
(0.03)\end{array}$ & $\begin{array}{c}0.32 * * * \\
(0.06)\end{array}$ & $\begin{array}{l}0.58 * * * \\
(0.04)\end{array}$ & $\begin{array}{l}0.34 * * * \\
(0.05)\end{array}$ & $\begin{array}{l}0.55 * * * \\
(0.07)\end{array}$ & $\begin{array}{l}0.34 * * * \\
(0.05)\end{array}$ \\
\hline Uncertainty & $\begin{array}{c}0.04 \\
(0.03)\end{array}$ & $\begin{array}{c}-0.19 * * * \\
(0.04)\end{array}$ & $\begin{array}{c}0.12 * * * \\
(0.04)\end{array}$ & $\begin{array}{c}-0.17 * * * \\
(0.05)\end{array}$ & $\begin{array}{c}0.04 \\
(0.07)\end{array}$ & $\begin{array}{c}-0.16 * * * \\
(0.04)\end{array}$ \\
\hline Market down & $\begin{array}{l}-0.04 \\
(0.04)\end{array}$ & $\begin{array}{c}-0.28 * * * \\
(0.04)\end{array}$ & $\begin{array}{l}-0.05 \\
(0.05)\end{array}$ & $\begin{array}{c}-0.18 * * * \\
(0.04)\end{array}$ & $\begin{array}{l}-0.10 \\
(0.08)\end{array}$ & $\begin{array}{c}-0.25 * * * \\
(0.05)\end{array}$ \\
\hline Growing Market & $\begin{array}{c}0.18 * * * \\
(0.04)\end{array}$ & $\begin{array}{l}0.16 * * * \\
(0.05)\end{array}$ & $\begin{array}{l}0.09 * \\
(0.05)\end{array}$ & $\begin{array}{c}0.19 * * * \\
(0.04)\end{array}$ & $\begin{array}{c}0.08 \\
(0.08)\end{array}$ & $\begin{array}{c}0.16 * * * \\
(0.05)\end{array}$ \\
\hline Export & $\begin{array}{l}0.20^{*} \\
(0.10)\end{array}$ & $\begin{array}{c}1.01 * * * \\
(0.13)\end{array}$ & $\begin{array}{l}0.19^{*} \\
(0.11)\end{array}$ & $\begin{array}{c}1.10^{* * * *} \\
(0.11)\end{array}$ & $\begin{array}{c}0.41 * * * \\
(0.15)\end{array}$ & $\begin{array}{c}0.94 * * * \\
(0.14)\end{array}$ \\
\hline $\mathrm{R} \& \mathrm{D}$ & $\begin{array}{c}0.40 * * * \\
(0.05)\end{array}$ & $\begin{array}{l}0.15^{*} \\
(0.08)\end{array}$ & $\begin{array}{c}0.63 * * * \\
(0.05)\end{array}$ & $\begin{array}{c}0.21 * * * \\
(0.06)\end{array}$ & $\begin{array}{c}0.88 * * * \\
(0.07)\end{array}$ & $\begin{array}{c}0.14 * * \\
(0.07)\end{array}$ \\
\hline Advertising & $\begin{array}{c}0.43 * * * \\
(0.04)\end{array}$ & $\begin{array}{l}0.13 * * \\
(0.06)\end{array}$ & $\begin{array}{l}0.749 * * * \\
(0.05)\end{array}$ & $\begin{array}{c}0.13 * * * \\
(0.04)\end{array}$ & $\begin{array}{c}0.72 * * * \\
(0.10)\end{array}$ & $\begin{array}{c}0.13 * * * \\
(0.04)\end{array}$ \\
\hline Consumption goods & $\begin{array}{c}-0.31 * * * \\
(0.09)\end{array}$ & $\begin{array}{c}-0.01 \\
(0.11)\end{array}$ & $\begin{array}{c}-0.59 * * * \\
(0.11)\end{array}$ & $\begin{array}{c}-0.09 \\
(0.10)\end{array}$ & $\begin{array}{c}-0.64 * * * \\
(0.17)\end{array}$ & $\begin{array}{l}-0.14 \\
(0.11)\end{array}$ \\
\hline Equipment goods & $\begin{array}{c}0.03 \\
(0.08)\end{array}$ & $\begin{array}{c}-0.20 * * * \\
(0.09)\end{array}$ & $\begin{array}{l}-0.06 \\
(0.09)\end{array}$ & $\begin{array}{c}-0.21 * * * \\
(0.08)\end{array}$ & $\begin{array}{c}-0.30 * * \\
(0.13)\end{array}$ & $\begin{array}{c}-0.25^{*} * * \\
(0.10)\end{array}$ \\
\hline Sales & $\begin{array}{c}-0.17 * * * \\
(0.06)\end{array}$ & $\begin{array}{c}0.18 * * * \\
(0.07)\end{array}$ & $\begin{array}{c}-0.22 * * * \\
(0.07)\end{array}$ & $\begin{array}{l}0.11^{*} \\
(0.06)\end{array}$ & $\begin{array}{c}-0.31 * * * \\
(0.09)\end{array}$ & $\begin{array}{c}0.09 \\
(0.07)\end{array}$ \\
\hline Construction & $\begin{array}{c}-0.07 \\
(0.07)\end{array}$ & $\begin{array}{c}-0.38 * * * \\
(0.07)\end{array}$ & $\begin{array}{c}-0.26^{* * *} * \\
(0.08)\end{array}$ & $\begin{array}{c}-0.33 * * * \\
(0.07)\end{array}$ & $\begin{array}{c}-0.34 * * * \\
(0.12)\end{array}$ & $\begin{array}{c}-0.41 * * * \\
(0.08)\end{array}$ \\
\hline Finance and real estate & $\begin{array}{l}-0.15^{*} \\
(0.08) \\
\end{array}$ & $\begin{array}{c}0.32 * * * \\
(0.10)\end{array}$ & $\begin{array}{c}-0.47 * * * \\
(0.11)\end{array}$ & $\begin{array}{c}0.30 * * * \\
(0.10)\end{array}$ & $\begin{array}{c}-0.92 * * * \\
(0.20)\end{array}$ & $\begin{array}{c}0.08 \\
(0.12) \\
\end{array}$ \\
\hline Agri-food & $\begin{array}{c}0.07 \\
(0.09)\end{array}$ & $\begin{array}{c}-0.19^{*} \\
(0.11)\end{array}$ & $\begin{array}{c}0.13 \\
(0.09)\end{array}$ & $\begin{array}{c}-0.12 \\
(0.10)\end{array}$ & $\begin{array}{c}0.08 \\
(0.14) \\
\end{array}$ & $\begin{array}{c}-0.32 * * \\
(0.13)\end{array}$ \\
\hline Service to firms & $\begin{array}{c}-0.22 * * * \\
(0.06)\end{array}$ & $\begin{array}{c}-0.53 * * * \\
(0.07)\end{array}$ & $\begin{array}{c}-0.47 * * * \\
(0.07)\end{array}$ & $\begin{array}{c}-0.62 * * * \\
(0.07)\end{array}$ & $\begin{array}{c}-0.91 * * * \\
(0.121)\end{array}$ & $\begin{array}{c}-0.67 * * * \\
(0.08)\end{array}$ \\
\hline Transportation & $\begin{array}{c}-0.26 * * * \\
(0.07)\end{array}$ & $\begin{array}{c}-0.57 * * * \\
(0.08)\end{array}$ & $\begin{array}{c}-0.45 * * * \\
(0.09)\end{array}$ & $\begin{array}{c}-0.60 * * * \\
(0.08)\end{array}$ & $\begin{array}{c}-0.741 * * * \\
(0.139)\end{array}$ & $\begin{array}{c}-0.63 * * * \\
(0.09)\end{array}$ \\
\hline Constant & $\begin{array}{c}-0.90 * * * \\
(0.07)\end{array}$ & $\begin{array}{c}0.78^{* * * *} \\
(0.10)\end{array}$ & $\begin{array}{c}-1.74 * * * \\
(0.08)\end{array}$ & $\begin{array}{c}0.83 * * * \\
(0.07)\end{array}$ & $\begin{array}{c}-2.573 * * * \\
(0.139)\end{array}$ & $\begin{array}{c}0.91 * * * \\
(0.08)\end{array}$ \\
\hline Observations & 7,433 & 7,433 & 6,719 & 6,719 & 5,151 & 5,151 \\
\hline
\end{tabular}

$(*),(* *),(* * *)$ indicate parameter significance at the 10, 5 and 1 per cent level, respectively. 